\title{
Hubungan Pemberian Kolostrum dengan Kejadian Stunting di Posyandu Desa Bonde
}

\author{
Amelia $^{1}$, Eva Yuliani ${ }^{2}$, Muhammad Irwan ${ }^{2}$ \\ ${ }^{1}$ Mahasiswa Fakultas Ilmu Kesehatan Unsulbar, \\ 2, Dosen Ilmu Keperawatan Fikes Unsulbar,
}

\section{Keywords :}

Balita Usia 25-60 Bulan, Stunting, Kolostrum.

\section{Kontak :}

Amelia

Email :

ameliafaiqah310897@gmail.com

Program Studi Ilmu Keperawatan,

Fakultas Ilmu Kesehatan, Universitas

Sulawesi Barat

DOI : https://doi.org/10.15294/

kemas.v14i3.1562

C)2020J-Healt

ini adalah artikel dengan akses terbuka dibawah licenci CC BY-NC-4.0

https://creativecommons.org/licenses/by-nc/4.0/

\begin{abstract}
Colostrum is the first stage liquid of breast milk produced during the mass of pregnancy. Colostrum contains high protein, fat-soluble vitamins and minerals. In addition, in colostrum there are also immunoglobin substances which are antibodies from the mother to the baby that function as passive immunity for the baby. This passive immunity will serve to protect the baby from harmful bacteria and viruses in the first year of birth. The purpose of this study is to see whether there is a relationship between the provision of colostrum and the incidence of stunting in toddlers aged 2560 months in Posyandu, Bonde Village. This type of research is an observational analytic study with a cross sectional study approach with the method of Simple Random Sampling and the instruments used are microtoise and graphs and questionnaires about administering colostrum. The sample used was toddlers aged 25-60 months as many as 75 respondents. Chi Square test analysis results showed that the $p$ value of 0.137 , which means greater than 0.05 ( $p>0.05)$. So it can be concluded that there is no significant relationship between the incidence of colostrum with the incidence of stunting in toddlers aged 25-60 months. Suggestions for future researchers to be able to add factors that can influence the occurrence of stunting and it is advisable to choose another place.
\end{abstract}




\section{PENDAHULUAN}

Masalah gizi yang paling banyak ditemukan di Indonesia adalah stunting, yaitu gangguan pertumbuhan yang terjadi akibat kondisi kekurangan gizi kronis dan penyakit infeksi kronis (Nuryanto 2016). Indonesia masih menghadapi permasalahan gizi yang berdampak serius terhadap kualitas sumber daya manusia (SDM) seperti kegagalan pertumbuhan dimana perkembangan selanjutnya seorang anak yang kurang gizi akan mengalami hambatan kognitif dan kegagalan pendidikan sehingga berdampak pada rendahnya produktivitas di masa dewasa.

Stunting merupakan gangguan pertumbuhan fisik yang ditandai dengan penurunan kecepatan pertumbuhan dan merupakan dampak dari ketidakseimbangan gizi. Menurut World Healt Organization (WHO) Child Growth Staba dan di banding standar, stunting didasarkan pada pada indeks panjang badan dibanding umur $(\mathrm{PB} / \mathrm{U})$ atau tinggi badan dibanding umur $(\mathrm{TB} / \mathrm{U})$ dengan batas (Z-score) kurang dari -2 SD (Standar Deviasi). Stunting masih merupakan suatu masalah gizi di Indonesia yang belum terselesaikan. Stunting akan menyebabkan dampak jangka panjang yaitu terganggunya perkembangan fisik, mental, intelektual serta kognitif (Kemenkes RI, 2016).

kejadian stunting dipengaruhi oleh beberapa factor, diantaranya adalah ASI eskslusif , berat badan lahir , asupan energy \& protein , status imunisasi, usia balita , jenis kelamin, status penyakit infeksi, pendidikan orang tua, dan status ekonomi keluarga (Oktarina dan Sudiarti , 2013). Menurut WHO 2013 dalam Lamid 2015 penyabab masalah stunting salah satunya ASI tidak eksklusif dan penyapihan ASI terlalu dini. Kolostrum adalah cairan tahap pertama Air Susu Ibu (ASI) yang dihasilkan selama massa kehamilan. Bagi orang awam kolostrum ini sering diartikan sebagai susu basi. Padahal kolostrum bukan susu basi melainkan susu yang kaya akan kandungan gizi dan zat imun.kolostrum mempunyai kandungan yang timggi protein, vitamin yang larut dalam lemak serta mineral. Selain iti, dalam kolostrum juga terdapat zat imunoglobin. Zat ini merupakan antibody dari ibu untuk bayi yang berfungsi sebagai imunitas pasif untuk bayi. Imunitas pasif ini yang akan berfungsi melindungi bayi dari bakteri dan virus yang merugikan pada tahun pertama kelahiran (Nirwana, 2014 )

Pemberian ASI yang kurang sesuai di Indonesia menyebabkan bayi menderita gizi kurang dan gizi buruk. Padahal kekurangan gizi pada bayi akan berdampak pada gangguan psikomotor, kognitif dan sosial serta secara klinis terjadi gangguan pertumbuhan. Pertumbuhan dan perkembangan pada masa bayi memerlukan masukan zat-zat gizi yang seimbang dan relative besar. Namun kemampuan bayi untuk makan dibatasi oleh keadaan saluran pencernaan bayi dan yang masih dalamtahap pendewasaan. Satu-satunya makanan yang sesua dengan keadaan saluran pencernaan bayi dan memenuhi kebutuhan selama berbulan-bulan pertama adalah ASI (Haryono dkk, 2014 ). Anak yang tidak mendapat ASI beresiko lebih tinggi untuk kekurangan zat gizi yang diperlukan untuk proses pertumbuhan. Gangguan pertumbuhan kan mengakibatkan terjadinya stunting pada anak (Anshori, 2013).

Berdasarkan hasil uraian diatas maka peneliti tertarik untuk meneliti tentang "Hubungan pemberian kolostrum dengan kejadian stunting anak usia 45 - 60 bulan di posyandu Desa Bonde".

\section{METODE}

Metode penelitian yang digunakan dalam penelitian ini adalah analitik observasional dengan pendekatan cross sectional yaitu mencari hubungan variabel independen (kolostrum) dengan variabel dependen (stunting). 
Tehnik sampling yang digunakan dalam pengambilan sampel ini adalah Simpel Random Samplin, dengan jumlah responden sebanyak 75 balita di Posyandu Desa Bonde. dengan Kriteria Inklusi responden yaitu balita berusia 25-60 bulan dan hadir saat penelitian yang bertempat tinggal di wilayah penelitian.

\section{HASIL}

\section{Karakteristik Responden}

Tabel 1

Distribusi Responden Berdasarkan jenis kelamin balita 25-60 bulan Di Posyandu Desa Bonde Tahun 2019

\begin{tabular}{cccc}
\hline No & $\begin{array}{c}\text { Jenis } \\
\text { Kelamin }\end{array}$ & n & $(\boldsymbol{\%})$ \\
\hline 1 & Laki-laki & 25 & 51 \\
2 & Perempuan & 24 & 49 \\
\hline & Total & $\mathbf{4 9}$ & $\mathbf{1 0 0 , 0}$
\end{tabular}

Sumber: Data Primer 2019
Tabel 2

Distribusi Responden Berdasarkan Tinggi Badan balita 25-60 bulan Di Posyandu Desa Bonde Tahun 2019

\begin{tabular}{cccc}
\hline No & Jenis Kelamin & $\mathbf{n}$ & $\mathbf{( \% )}$ \\
\hline 1 & Sangat Pendek & 36 & 48,0 \\
2 & Pendek & 22 & 29,3 \\
3 & Normal & 17 & 22,7 \\
\hline & Total & $\mathbf{7 5}$ & $\mathbf{1 0 0 , 0}$ \\
\hline
\end{tabular}

Sumber: Data Primer 2019

Tabel 3

Distribusi Responden Berdasarkan Pemberian Kolostrum pada balita 25-60 bulan Di Posyandu Desa Bonde Tahun 2019

\begin{tabular}{cccc}
\hline No & $\begin{array}{c}\text { Pemberian } \\
\text { Kolostrum }\end{array}$ & n & $(\boldsymbol{\%})$ \\
\hline 1 & Diberikan & 69 & 92,0 \\
2 & Tidak Diberikan & 6 & 8,0 \\
\hline & Total & $\mathbf{7 5}$ & $\mathbf{1 0 0 , 0}$
\end{tabular}

Sumber: Data Primer 2019

\section{Analisis Bivariat}

\section{Tabel 4}

Analisa hubungan Pemberian Kolostrum dengan Kejadian Stunting pada Balita Usia 25-60 bulan di Posyandu Desa Bonde Tahun 2019

\begin{tabular}{lccccccc}
\hline \multicolumn{7}{c}{ Kejadian Stunting } \\
\hline Pemberian Kolostrum & Stunting & Normal & & Total & $\begin{array}{c}\text { P } \\
\text { Value }\end{array}$ \\
\hline & $\mathrm{N}$ & $\%$ & $\mathrm{~N}$ & $\%$ & $\mathrm{~N}$ & $\%$ & \\
Diberikan & 50 & 67 & 19 & 25 & 69 & 92 & $\mathbf{0 , 1 3 7}$ \\
Tidak Diberikan & 6 & 8 & 0 & 0 & 6 & 8 & \\
\hline Total & $\mathbf{5 6}$ & $\mathbf{7 5}$ & $\mathbf{1 9}$ & $\mathbf{2 5}$ & $\mathbf{7 5}$ & $\mathbf{1 0 0 \%}$ & \\
\hline
\end{tabular}


Berdasarkan hasil analisis menggunakan uji statistik Chi-Square, menunjukkan tidak ada hubungan yang signifikan antara kejadian stunting dengan tingkat perkembangan yaitu masing-masing menunjukkan $p$-value lebih dari 0.05 (0.37). Hasil penelitian menunjukkan Pemberian Colostrum Tidak Terhadap Kejadian Stunting. Terlihat pada tabel bahwa dari 75 responden terdapat 69 (92\%) responden yang diberikan Colustrum dan yang tidak diberkan Colostrum sebanyak 6 (8\%). Sedangkan pada responden dengan Diberikan Colostrum yang berada pada kirteria normal sebanyak 19 responden (25\%) sedangkan Diberikan colostrum dengan kategori Stunting sebanyak 50 responden (67\%) Berdasarkan hasil uji statistik Chi Square diperlihatkan nilai $\mathrm{p}: 0,137(\mathrm{p}<0.05)$, hal ini membuktikan bahwa terdapat Tidak ada Hubungan Pemberian Colostrum Terhadap Kejadian Stunting di Desa Bonde Kecamatan Pamboang 2019 karna dimana pemberian kolostrum dominan di berikan pada balita.

\section{PEMBAHASAN}

1. Mengidentifikasi karakteristik pada responden.

a. Karakteristik Responden Berdasarkan Umur

umur responden yang banyak yaitu kelompok umur 3 tahun dengan jumlah 24 responden $(32,0 \%)$ sedangkan paling sedikit 5 Tahun dengan jumlah 15 responden (20\%). Penelitian yang dilakukan oleh Irwansyah, Ismail, \& Hakimi (2016) yang menyatakan bahwa kehamilan usia remaja ( $<20$ tahun) berisiko 2,9 kali lebih banyak dijumpai pada anak stunting dibandingkan dengan anak yang tidak stunting).

Dampak dari umur yang terlalu muda mengakibatkan pertumbuhan anak yang tdk optimal dan tidak terencana dengan umur responden juga menetukan kematangan ibu siap untuk menghadapi kehamilan termasuk bertindak untuk memberikan gizi kapada anaknya.

b. Karakteristik Responden Berdasarkan Jenis Kelamin

jenis kelamin responden yang paling banyak yaitu laki-laki dengan jumlah 46 responden $(61,3 \%)$ dan perempuan yaitu adalah $29(38,7 \%)$.

Jenis kelamin anak kebanayakan adalah laki-laki pada penelitian ini. Gershwin (2014) pada tahun pertama laki laki lebih berisiko malnutrisi karena ukuran tubuh lebih besar dan membutuhkan asupan lebih besar, jika tidak terpenuhi dalam jangka waktu lama akan meningkatkan risiko gangguan pertumbuhan.

Pada tahun pertama kehidupan, lakilaki lebih rentan mengalami malnutrisi daripada perempuan karena ukuran tubuh laki-laki yang besar dimana membutuhkan asupan energi yang lebih besar pula sehingga bila asupan makan tidak terpenuhi dan kondisi tersebut terjadi dalam jangka waktu lama dapat meningkatkan gangguan pertumbuhan.

Penelitian (Adianti, 2010), Hasil penelitiannya adalah bayi laki-laki cenderung mejadi stunting saat memasuki usia satu tahun, dan bayi perempuan pada usia dua tahun. Hal ini terkait pola asuh orang tua dalam memberikan makanan pada anak. Sinha, et al., (2018) dalam penelitiannya menunjukkan hasil bahwa kejadian wasting, stunting dan undernutrition secara signifikan lebih umum terjadi pada anak laki-laki daripada anak perempuan

c. Karakteristik Responden Berdasarkan Tinggi Badan

Karakteristik responden berdasarkan tinggi badan. Berdasarkan tinggi badan paling banyak adalah sangat pendek $36(48,0 \%)$, dan tinggi badan terendah adalah normal $17(22,7 \%)$.

Panjang badan lahir yang dikategorikan normal $(\geq 48 \mathrm{~cm})$ dan 
pendek (<48 cm) (Kemenkes RI, 2016). Penelitian kasus kontrol pada balita usia 12 bulan dengan sampel sebanyak 24 anak di Kecamatan Patebon Kabupaten Kendal menunjukkan bahwa panjang badan lahir panjang badan lahir rendah merupakan salah satu faktor risiko terjadinya stunting pada balita menurut Meilyasari dan Isnawati (2013). Penelitian di Pati yang menunjukkan hasil bahwa panjang badan lahir merupakan faktor risiko kejadian stunting pada anak usia 12-36 bulan, dan penelitian di Indramayu yang menunjukkan hasil bahwa anak yang lahir dengan panjang badan dibawah persentil 10 lebih berisiko tumbuh stunting (Anugrahen HS, 2012). Bayi dengan panjang badan lahir pendek berpeluang lebih tinggi untuk tumbuh pendek dibanding anak panjang badan lahir normal (Kusharisupeni, 2010).

2. Mengidentifikasi Analisa Pemberian Colostrum Terhadap Kejadian Stunting

Dari 75 responden terdapat 69 (92\%) responden yang diberikan Colustrum dan yang tidak diberkan Colostrum sebanyak 6 (8\%). Sedangkan pada responden dengan Tidak Diberikan Colostrum yang berada pada kirteria normal sebanyak 19 responden $(25 \%)$ sedangkan tidak diberikan colostrum dengan kategori Stunting sebanyak 50 responden (67\%) Berdasarkan hasil uji statistik Chi Square diperlihatkan nilai $\mathrm{p}: 0,137$ ( $\mathrm{p}<0.05)$, hal ini membuktikan bahwa terdapat Tidak ada Hubungan Pemberian Colostrum Terhadap Kejadian Stunting Pada Balita usia 25-60 bulan di Desa Bonde Kecamatan Pamboang. Sesuai dengan penelitian yang dilakukan oleh Setiwan, Machmud, \& Masrul (2018), dengan judul Faktor-Faktor Berhubungan dengan Kejadian Stunting, dengan hasil tidak ada hubungan pada pemberian ASI eksklusif justru pada asupan yang diluar anak mengingat anak kebanyakan >3 tahun keatas banyak membutuhkan asupan dari luar juga.

Bertentangan dengan teori manfaat ASI tetapi ada faktor lain yang berkaitan dengan kejadian stunting yaitu Hubungannya antara tingkat asupan energi dengan kejadian stunting secara statistik bermakna. Hasil yang sama diperoleh pada penelitian yang dilakukan di Kelurahan Kejawan Putih Tambak, Kecamatan Mulyorejo, Kota Surabaya, yaitu terdapat perbedaan tingkat kecukupan asupan energi yang signifikan antara balita stunting dan non stunting (Darmayanti, Muniroh, \& Parfti, 2016)

Masa awal anak-anak ditandai dengan pertumbuhan yang cepat (growth spurt). Mencukupi kebutuhan asupan energi yang adekuat merupakan hal yang sangat penting bagi anak. Energi tersebut bersumber dari makronutrien seperti: karbohidrat, lemak, dan protein. Karbohidrat merupakan sumber energi yang secara kuantitas paling penting bagi tubuh. Karbohidrat menyediakan energi untuk seluruh jaringan di dalam tubuh, terutama di otak yang normalnya menggunakan glukosa sebagai sumber energi aktivitas sel. Protein merupakan zat yang esensial bagi sel-sel tubuh. Lemak yang dikonsumsi dalam makanan dijadikan sebagai sumber energi dan asam lemak esensial. Asam lemak struktural merupakan bagian penting dari membran sel, serabut saraf, dan struktur sel secara umum. Cadangan lemak terutama pada jaringan adiposa sebagai sumber energi jangka panjang bagi tubuh (Barilla, 2011)

Hubungan antara tingkat asupan protein dengan kejadian stunting secara statistik tidak menunjukkan signifikansi. Hasil penelitian yang sama diperoleh pada penelitian yang dilakukan di Kelurahan Bandar Buat, Kecamatan Lubuk Kilangan, Kota Padang, yaitu tidak terdapat hubungan yang signifikan antara tingkat asupan protein dengan kejadian stunting pada siswa kelas I sekolah dasar (Sulastri,2012)

Hal ini dengan teori dapat disebabkan asupan protein yang dikonsumsi dijadikan sebagai sumber energi. Protein merupakan satu dari tiga sumber energi utama bagi tubuh. Pemecahan protein akan terjadi apabila asupan energi tidak adekuat. Tubuh akan mengalami defisiensi protein apabila 
diet tidak mengandung protein dan/ atau energi dalam jumlah yang dibutuhkan.

Ketidaksesuain ini juga dapat disebabkan oleh metode pengukuran tingkat asupan nutrien dengan menggunakan FFQ semi kuantitatif. Menurut Sulastri, pengukuran tingkat asupan nutrien dengan menggunakan FFQ semi kuantitatif belum menggambarkan jumlah asupan nutrien yang sesungguhnya. Hal ini disebabkan karena metode ini dipengaruhi oleh faktor lain, seperti: daya ingat responden, waktu, serta suasana saat wawancara (Sulastri,2012).

\section{KESIMPULAN}

Hasil analisis menunjukkan bahwa tidak ada hubungan yang bermakna antara pemberian kolostrum dengan kejadian stunting pada balita usia 25-60 bulan di Posyandu Desa Bonde.

\section{SARAN}

Puskesmas beserta instansi terkait sebaiknya meningkatkan pemberian informasi kepada masyarakat mengenai stunting, melakukan deteksi dini resiko stunting melalui peningkatan pengetahuan dan kemampuan kader posyandu, perubahan pola pikir masyarakat dalam pola asuh anak yang bertentangan dengan kesehatan serta pemberian informasi tentang makanan yang mengandung protein dan energi tinggi yang mudah dijangkau dan disukai anak-anak.

\section{DAFTAR PUSTAKA}

Aditianti. 2010. Faktor Determinan Stunting Pada Anak Usia 24-59 Bulan di Indonesia. IPB. Tesis

Anshori, H. 2013. Faktor Risiko Kejadian Stunting Pada Anak Usia 12-24 Bulan (studi di Kecamatan Semarang Timur). Artikel Penelitian. Semarang: Universitas Diponegoro.

Barill, G. (2011). 2011 Double Pyramid: Healthy Food For People, Sustainable
For The Planet. Roma: Codice Edizioni.

Darmayanti, R.A., Muniroh, L., \& Farapti. (2016). Perbedaan tingkat kecukupan zat gizi dan riwayat pemberian asi eksklusif pada balita stunting dan non stunting. Media Gizi Indonesia. 11(1). http://dx.doi.org/10.20473/mgi.v11i1.61 $-69$

Haryono, R,. \& Setianingsih, S. (2014). Manfaat Asi Ekslusif Untuk Buah Hati Anda. Yogyakarta: Gosyen Publishing.

Irwansyah, Ismail, D., \& Hakim, M. (2016). Kehamilan remaja dan kejadian stunting anak usia $6-23$ bulan di Lombok Barat. BKM Journal of Community Medicine and Public Health, 32(6).

Kusharisupeni. (2010). Gizi dan Kesehatan Masyarakat. Departemen Gizi dan Kesehatan Masyarakat Universitas Indonesia (UI). Jakarta: Raja Grafindo Persada.

Kementrian Kesehatan RI. (2016). Situasi balita pendek. Info Datin, 24427659. https://doi.org/ISSN244.

Meliyasari, F., \& Isnawati, M. (2014). Aktor Risiko Kejadian Stunting Pada Balita Usia 12 Bulan Di Desa Purwokerto Kecamatan Patebon, Kabupaten Kendal. Journal of Nutrition College. 3(2). DOI: https://doi.org/10.14710/jnc.v3i2. 5437

Nirwana, A. B. 2014. ASI dan Susu Formula. Yogyakarta: Nuha Medika

Oktarina, Z., \& Sudiarti, T. (2014). Faktor Risiko Stunting Pada Balita (24-59 Bulan) Di Sumatera. Jurnal Gizi Dan Pangan, 8(3), 175-180.

Setiawan, E., Machmud, R., \& Masrul. (2018). Faktor-Faktor yang Berhubungan dengan Kejadian Stunting pada Anak Usia 24-59 Bulan di Wilayah Kerja Puskesmas Andalas Kecamatan Padang Timur Kota Padang Tahun 2018. Journal Kesehatan Andalas, $7(2)$. DOI: https://doi.org/10.25077/jka.v7i2. 
813

Sinha, R.K., Dua, R., Bijalwan, V., Rohatgi, S., \& Kumar, P. (2018). Determinants of Stunting, Wasting, and Underweight in Five High-Burden Pockets of Four Indian States. Indian J Community Med. Oct-Dec; 43(4): 279-283.

Sulastri, D. (2012). Faktor determinan kejadian stunting pada anak usia sekolah di kecamatan lubuk kilangan kota padang. Jurnal Majalah Kedokteran Andalas, 36(1): 39-50

Vaozia, S, \& Nuryanto. (2016). Faktor risiko kejadian stunting pada anak usia 1-3 tahun (Studi Di Desa Menduran Kecamatan Brati Kabupaten Grobogan). Journal of Nutrition College, 5(4), DOI: 10.14710/jnc.v5i4.16426 